\title{
Projektowanie i wytwarzanie lutowanych ram rowerowych
}

\section{Design and manufacture of brazed bicycle frames}

\section{Streszczenie}

W artykule przedstawiono możliwości zastosowania lutowania twardego do wytwarzania ram rowerowych. Opisano materiały stosowane na ramy rowerowe i techniki ich łączenia, ze szczególnym zwróceniem uwagi na technikę lutowania. Zaprezentowano trendy rozwojowe branży rowerowej. Wskazano problematykę lutowania głównych elementów ram i zaproponowano korzystne rozwiązania. Dokonano podziału metod spajania ram rowerowych na lutowanie bezpośrednie i z wykorzystaniem muf. Wskazano materiały dodatkowe najczęściej stosowane do lutowania profili ram rowerowych.

Słowa kluczowe: metody łączenia ram; materiały ram; lutowanie mufowe; lutowanie stykowe

\begin{abstract}
Applicability of brazing for bicycle frames manufacture was presented in this paper. Materials used for bicycle frames and their joining techniques, with particular attention paid to brazing methods were described. Development trends in bicycle craft were characterized. Issues in brazing of bicycle frames main elements were indicated and beneficial solutions were proposed. Bicycle frames joining methods were divided into fillet brazing and lugged brazing. Additional filler materials the most commonly used for brazing of bicycle frames pipes were indicated.
\end{abstract}

Keywords: methods of bicycle frames joining; bicycle frames materials; lugged brazing; fillet brazing

\section{Wprowadzenie}

Historia rowerów ewoluowała od bardzo prymitywnych konstrukcji, zwanych maszynami do biegania (nieskrętne pojazdy wymagające odpychania), poprzez formy częściowo udoskonalane, w których kolejno wprowadzano: widelec skrętny, hamulce, regulowane siedzenie, napęd korbowy (bicykle), metalowe ramy i obręcze kół, napęd łańcuchowy, pneumatyczne opony... Aż do dnia dzisiejszego, kiedy wytwarzane rowery są konstrukcjami bardzo zaawansowanymi, zarówno materiałowo, jak i technologicznie. Aktualnie na świecie produkuje się około 260 rowerów na minutę tj. ponad 130 milionów rocznie (ok. 3 razy więcej niż samochodów), z czego średnio 80-90 milionów wytwarzanych jest w Chinach [1,2]. Z uwagi na czynniki ekonomiczne oraz możliwości wytwórcze w Europie produkcja ram jest zasadniczo nieopłacalna. Nawet najpopularniejsze firmy Starego Kontynentu sprowadzają wyroby z Azji. Polacy kupują ponad milion rowerów rocznie, a w naszym kraju na 100 mieszkańców przypadają 22 rowery (średnia europejska 46, w Amsterdamie 70) [3]. Około $74 \%$ gospodarstw ma przynajmniej jeden rower, choć statystyki te zawyżają gospodarstwa wiejskie, gdzie często rower to jedyny środek komunikacji. Potwierdzają to badania CBOS, z których wynika, że mimo iż na rowerze jeździ $70 \%$ Polaków, to tylko $22 \%$ robi to systematycznie [4].

Integralnym, a przy tym często najdroższym elementem roweru jest rama, decydująca o jego charakterze i przeznaczeniu. Aktualnie na rynku są już dostępne obliczeniowe programy projektowo-konstrukcyjne, dedykowane projekto-

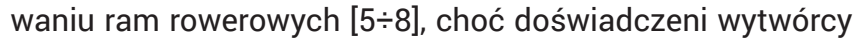
ram typowych konstrukcji rzadko z nich korzystają. Głównym czynnikiem decydującym o doborze odpowiedniej konstrukcji ramy jest zakładany sposób jej użytkowania. Nie można jednoznacznie stwierdzić, że istnieją ramy uniwersalne, które mogą być dowolnie eksploatowane wg preferencji użytkownika, gdyż właściwy sposób ich wykorzystania, zależy od wielu aspektów: czysto technicznych - konstrukcja, technologia, jak i subiektywnych - komfort jazdy. Wybór właściwej geometrii ramy jest kluczowym etapem, który powinien być rozważony podczas zakupu roweru, gdyż na jego podstawie w efekcie dobiera się pozostałe podzespoły. Najważniejszymi czynnikami wpływającymi na wytrzymałość i trwałość ramy, ale także estetykę i czynnik ekonomiczny są materiały elementów składowych i sposoby ich łączenia.

Dr inż. Tomasz Piwowarczyk - Politechnika Wrocławska.

Autor korespondencyjny/Corresponding author: tomasz.piwowarczyk@pwr.edu.pl 


\section{Materiały stosowane do produkcji ram rowerowych}

Ramy rowerowe, mimo często prostej konstrukcji, muszą wykazywać szereg cech, niezbędnych do ich właściwej i możliwie długiej eksploatacji. Aktualne trendy branży rowerowej stawiają ramom wiele wymagań, których spełnienie w znacznym stopniu przyczynia się do zapewnienia komfortu jazdy. Rama powinna być przede wszystkim lekka, trwała, dobrze absorbująca drgania, przy jednoczesnym zachowaniu wystarczającej sztywności, aby bez strat przenosić siłę z pedałów do układu napędowego. Nie powinna być podatna na zjawisko zmęczenia materiałowego. Zalecane jest również, aby wykazywała wytrzymałość na obciążenia zmienne, odporność na gięcie boczne oraz momenty skręcające. Finalnie musi posiadać atrakcyjny wygląd, co jest w wielu przypadkach czynnikiem decydującym w podejmowaniu decyzji zakupu roweru (zatem nawet proces lakierowania również jest istotny), oraz charakteryzować się odpornością na niekorzystne wpływy atmosferyczne. Większość tych cech (gęstość, sztywność, wydłużenie, wytrzymałość, trwałość, udarność) zależy zarówno od materiału, z jakiego rama jest wykonana, jak i jej kształtu i wymiarów. Ramy rowerowe wykonywane są najczęściej w całości z jednego materiału, można jednak spotkać konstrukcje, gdzie stosuje się dwa lub nawet trzy różne ich rodzaje.

Materiały wykorzystywane $\mathrm{w}$ produkcji ram podane w kolejności wprowadzania na rynek rowerowy to: drewno (głownie bambus), różne gatunki stali, stopy aluminium, kompozyty z włóknem węglowym, stopy magnezu, stopy

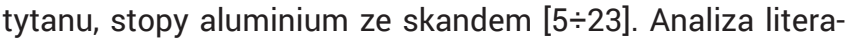
tury obejmującej zakresem tematykę wytwarzania ram rowerowych wyraźnie wskazuje na czynnik materiałowy, jako dominujący trend $w$ rozwoju tych konstrukcji $[5 \div 8,11 \div 14]$. Spośród prac publikowanych w ostatnich latach szczególny nacisk położono na dwie grupy materiałowe: kompozyty $[5 \div 7,9,11,12,14]$ i stopy aluminium $[8,13,16 \div 18]$.

Stal, przy relatywnie niskiej cenie, jest materiałem o największym współczynniku sprężystości, największej gęstości i wytrzymałości na rozciąganie [17]. Mimo pojawienia się na rynku wielu nowych, często zaawansowanych tworzyw, nadal spośród jej licznych gatunków, różniących się przede wszystkim sztywnością i gęstością, wytwarza się ramy rowerowe. Podstawowym gatunkiem przeznaczonym na ramy rowerowe są stale konstrukcyjne o podwyższonej wytrzymałości oznaczane Hi-Ten (High Tensile). Wytwarza się je poprzez kształtowanie cylindrycznego profilu plastycznej jeszcze stali, a następnie ciągnienie, walcownie i kucie gotowej, już ostudzonej rury. Mimo mylnej nazwy charakteryzują się niewielkimi parametrami wytrzymałościowymi i wysokim ciężarem właściwym, zatem w celu uzyskania wymaganych wskaźników wytrzymałościowych, wymagane jest zastosowanie większych grubości ścianek, co skutkuje podniesieniem masy roweru.

Lepszymi parametrami charakteryzują się gatunki stopowych stali chromowo - molibdenowych, oznaczanych umownie Cr-Mo (np. 25CrMo4/4130). Oba pierwiastki stopowe poprawiają hartowność stali i zwiększają ich wytrzymałość. Dodatkowo chrom powoduje rozdrobnienie ziarna, a molibden zmniejsza kruchość oraz podnosi odporność na pełzanie. Stale te wykazują w porównaniu z aluminium nawet 6-krotnie większą wytrzymałość mechaniczną $\left(R_{m}\right.$ do $\left.1300 \mathrm{MPa}\right)$, 3-krotnie większą sztywnością i 5-krotnie większą granicę plastyczności $[16,17,19,23]$. Pozwala to na wytwarzanie bardzo lekkich ram (masa do $1 \mathrm{~kg}$ ), przy niewielkich średnicach rurek i grubości ścianek nawet 0,7-0,4 mm (dzisiaj 0,38 mm) [16,20]. Ponadto ramy te bardzo dobrze tłumią drgania, są mniej podatne na pękanie, a $w$ razie konieczności proste do naprawy metodami spawalniczymi. Zazwyczaj wytrzymałość na rozciąganie tych ram wynosi 700-900 MPa, ale ich ostateczne właściwości zależą od ilości dodatków stopowych oraz ewentualnej obróbki (dzisiaj dla ram stalowych zasadniczo obróbki cieplnej po spawaniu w zasadzie się już nie stosuje) [23].

Aktualnie, oprócz wspomnianych wyżej popularnych gatunków stali, spotyka się na rynku ramy [23]:

- z ciągnionych na zimno stali bainitycznych hartowanych w powietrzu, o wysokiej plastyczności i trwałości zmęczeniowej oraz wytrzymałości na poziomie 1250-1400 $\mathrm{MPa}$,

- z przerobionych plastycznie na zimno austenitycznych stali chromowo-niklowych ze znacznym dodatkiem manganu (na poziomie 9\%) i azotu, o wytrzymałości powyżej $1000 \mathrm{MPa}$,

- z umacnianych wydzieleniowo nierdzewnych stali chromowo-niklowych z miękkim martenzytem (typu X5CrNiCuNb 16-4) o wytrzymałości na poziomie $1300 \mathrm{MPa}$,

- ze stali maraging o wytrzymałości w zakresie 1750-2050 $\mathrm{MPa}$, najczęściej z dodatkiem niklu na poziomie $18-25 \%$, w których mechanizm umacniania bazuje na wydzielaniu faz międzymetalicznych w osnowie typu martenzytycznego z końcowym procesem starzenia.

Przy stalach bardzo zaawansowanych technologicznie, a przy tym oferujących najlepsze parametry wytrzymałościowe, obróbka cieplna często bywa bardzo skomplikowana.

Trendy rozwojowe w produkcji ram rowerowych zmusiły wytwórców do zwrócenia się w kierunku stopów lekkich. Chętnie stosowanym materiałem jest aluminium, którego ciężar właściwy wynosi zaledwie $2,7 \mathrm{~kg} / \mathrm{dm}^{3}$ (2-3 razy mniej od stali) [2]. W praktyce ramy aluminiowe są lżejsze od swoich konstrukcyjnych odpowiedników stalowych o 300-500 g. Z uwagi na niewystarczającą sztywność i wytrzymałość czystego aluminium, powszechnie wykorzystuje się stopy z dodatkami miedzi, cynku, krzemu, magnezu i manganu. Dzięki takiemu zabiegowi, przy niewielkim wzroście masy ramy, można uzyskać wymagane parametry wytrzymałościowe. Oprócz mniejszej wytrzymałości mechanicznej w porównaniu ze stalą, ramy aluminiowe charakteryzują się znaczną sztywnością, co wprawdzie polepsza sterowność pojazdu, ale jednocześnie przekłada się na brak komfortu przy pokonywaniu nierówności [10]. W celu zmniejszenia oddziaływania wibracji często taką ramę komponuje się z karbonowym widelcem i/lub karbonową sztycą (wspornikiem siodła). Niższe wskaźniki wytrzymałościowe ram ze stopów aluminium kompensuje się zwykle większą średnicą rur (w stosunku do stalowych), przy tej samej grubości ścianki. Należy tu zaznaczyć, że profile aluminiowe z których buduje się ramy rzadko mają przekrój kołowy. Dzisiaj ich kształt jest optymalizowany przez hydroformowanie. Najczęściej stosowanymi stopami aluminium do produkcji ram rowerowych są stopy serii $6 x x x$ (z magnezem i krzemem) i 7xxx (z cynkiem, tzw. "durale cynkowe"), rzadziej 5xxx (z magnezem,

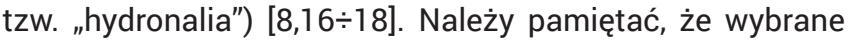
stopy aluminium, zwłaszcza utwardzane wydzieleniowo stopy serii 6xxx i 7xxx (np. przemysłowy standard w produkcji ram - stop 6061), tracą po procesie spawania swoje wysokie właściwości wytrzymałościowe i wymagają ponownej obróbki cieplnej [9]. Ostatnio obserwuje się zainteresowanie (jeszcze relatywnie drogimi) stopami aluminium zawierającymi skand, które z uwagi na wyższe parametry wytrzymałościowe, pozwalają na wytwarzanie ram z elementów o cieńszych grubościach ścianek, a przez to lepiej absorbujących wibracje podczas jazdy.

Bardzo dobre właściwości użytkowe wykazują ramy ze stopów tytanu $[9,10]$. Charakteryzują się lekkością, 
wysoką wytrzymałością, odpowiednią sztywnością (tłumienie drgań), odpornością na czynniki atmosferyczne oraz, w zależności od wybranego stopu, wieloma innymi zaletami. Najczęściej spotykany stop nosi oznaczenie Ti3Al2,5V i obok tytanu zawiera aluminium i wanad [10]. Z uwagi na wysoką jakość ramy te są stosunkowo drogie. Ramy tytanowe w opinii producentów uchodzą za niezniszczalne, choć użytkownicy, zwłaszcza intensywnie eksploatujący rowery, nie zawsze zgadzają się z tą opinią.

Do produkcji kompozytowych ram rowerowych używa się włókien węglowych (karbonu) lub/i aramidowych (kevlaru), nasączanych żywicami, najczęściej epoksydowymi [5$7,9,11,12,14]$. Niekiedy wzmacnia się je elementami ze stopów metali lekkich. Kombinacja tych składników pozwala na stworzenie ramy o dowolnie zaplanowanych parametrach. Ich największą zaletą jest mała masa, nawet około $600 \mathrm{~g}$ (30\% mniej od stopów metali) [5], choć w celu zapewnienia właściwej wytrzymałości zwykle oscyluje wokół $1 \mathrm{~kg}$. Oprócz tego wykazują bardzo dobrą sztywność przy odpowiednim tłumieniu nierówności, nie ulegają korozji i mają nieograniczone możliwości formowania, łącznie z nadawaniem sztywności w zaplanowanych kierunkach. Przyjmuje się, że dobrej jakości kompozyt ma do 2,5 razy większą wytrzymałość niż stal [5].

\section{Metody łączenia ram rowerowych}

Bazą konstrukcji większości typów ram rowerowych są trapez i tylny trójkąt, zatem największe naprężenia koncentrują się zazwyczaj w miejscach łączenia poszczególnych elementów. Obok czynnika materiałowego, o wytrzymałości i funkcjonalności ramy, decydują więc węzły łączące, a konkretnie jakość połączeń uzyskanych wybraną techniką spajania. W zależności od dobranej technologii, wymagany jest dodatkowo odpowiedni stopień przygotowania elementów do spajania, np. wykończenie powierzchni rur.

Aktualnie w wytwarzanych ramach rowerowych przeważają węzły spawane, lutowane czy klejone/laminowane, choć zdarzały się ramy skręcane, a nawet nitowane. Wybór odpowiedniej techniki łączenia nie wypływa jedynie na wytrzymałość konstrukcji, ale determinuje również jej cechy użytkowe i komfort jazdy oraz w znacznym stopniu decyduje o kosztach. Istnieją technologie wręcz dedykowane produkcji wielkoseryjnej (spawanie), ale również typowo manualne, wskazane przy popularnym w branży rowerowej wytwarzaniu jednostokowym dopasowanym do wymagań klienta (lutowanie bezpośrednie, tzw. stykowe). Nie można natomiast jednoznacznie stwierdzić, że istnieje najlepsza technika łączenia, gdyż jakość połączeń zależy od bardzo wielu czynników. Z drugiej strony każda z wymienionych metod wykonana właściwie (poprawnie opracowana technologia) będzie w zupełności wystarczająca, nawet dla największych obciążeń występujących w ramach.

Najczęściej wykorzystywaną techniką spajania elemen-

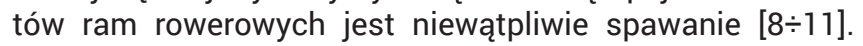
Kluczowym argumentem przemawiającym za stosowaniem tej techniki jest relatywnie niższy koszt, wysoka wydajność procesu i możliwość automatyzacji. W dzisiejszych czasach nawet przy wykorzystaniu niekoniecznie zaawansowanych technik spawania istnieje możliwość uzyskania połączeń przewyższających wytrzymałością mechaniczną wytrzymałość elementów łączonych. Należy jednak pamiętać, że sama spoina (poprawnie wykonana) ma zazwyczaj odpowiednio dużą wytrzymałość, natomiast newralgicznym obszarem jest powstała strefa wpływu ciepła (SWC), gdzie materiał w wyniku oddziaływania ciepła uległ zmianom strukturalnym, w efekcie czego często cechuje się niższymi wskaźnikami wytrzymałościowymi. Z uwagi na znaczy udział rynku ram aluminiowych, aktualnie najczęściej stosuje się spawanie w gazach ochronnych TIG (ewentualnie MIG), choć dla ram stalowych można zastosować inne metody. Z uwagi na naprężenia spawalnicze, będące efektem znacznego obciążenia cieplnego SWC, ramy spawane często wymagają przeprowadzenia dodatkowej obróbki cieplnej po procesie (zwłaszcza ramy wykonywane z serii $6 x x x$ i 7xxx) lub przynajmniej tzw. sezonowania. Dla niektórych materiałów można tak zaplanować produkcję, aby kolejny etap (np. malowanie proszkowe i utwardzanie w piecu), jednocześnie stanowił obróbkę cieplną.

Ramy kompozytowe z uwagi na specyfikę materiału wymagają diametralnie innych technik łączenia. Generalnie stosuje się dwie technologie wytwarzania: T2T i monocoque. Pierwsza metoda (tube to tube) z wykorzystaniem muf lub analogicznych niekoniecznie kompozytowych łączników jest bardziej uniwersalna, uchodzi za prostszą i bardziej ekonomiczną. Spoiwem najczęściej są kleje lub masy łączące na bazie żywic, zatem połączenia powstają w wyniku oddziaływań adhezyjnych. Poszczególne elementy (rury) mogą być wytwarzane w dłuższych odcinkach, a następnie docinane, obrabiane (powierzchnie łączone) i spajane. Druga metoda, zwana powszechnie skorupową, polega na pokryciu rdzenia warstwami nasączonych żywicą tkanin (najczęściej karbon lub kevlar) w celu uzyskania zakładanego kształtu. Taka monolityczna rama może przyjmować dowolny kształt, jednak zazwyczaj jest stosunkowo droga. Niewątpliwą zaletą jest jednak możliwość wzmocnienia miejsc szczególnie narażonych na obciążenia podczas formowania - anizotropia konstrukcji. Aktualnie produkuje się ramy, w których łączy się obie technologie.

\section{Mechanizm łączenia lutowanych ram rowerowych}

Po spawaniu najczęściej stosowaną metodą łączenia elementów ram rowerowych jest lutowanie. Spośród zjawisk fizykochemicznych, zachodzących na granicy materiał - spoiwo w procesach lutowania twardego i wysokotemperaturowego największe znaczenie dla wytrzymałości połączenia mają zjawiska dyfuzji. O otrzymaniu poprawnego złącza decyduje również przygotowanie powierzchni materiałów lutowanych, wpływające bezpośrednio na zwilżalność ciekłym lutem i takie zjawiska powierzchniowe jak kapilarność i rozpływność. Zwilżalność w procesach lutowania to zdolność lutu do pokrywania powierzchni elementów łączonych cienką, równomierną i nieprzerwaną warstwą spoiwa. Ze zwilżalnością ściśle związana jest rozpływność, zależna od właściwości fizykochemicznych lutu i podłoża oraz wielkości sił adhezji na granicy łączenia. Jest to zdolność pokrywania możliwie największego obszaru materiału lutowanego przez ciekły lut. Wynika z tego jednoznacznie, że na rozpływność mają również wpływ właściwości powierzchniowe elementów łączonych takie jak np. chropowatość powierzchni czy ukierunkowanie nierówności [24].

\section{Przygotowanie elementów ramy do lutowania}

Prace konstrukcyjne zaczyna się od projektu geometrii ramy. W zależności od wybranego jej rodzaju, przy uwzględnieniu anatomii przyszłego użytkownika, należy wskazać nadrzędne wymiary i kąty, na podstawie których wyliczane 
są pozostałe zależności geometryczne. Na postawie założonych i obliczonych długości/kątów należy zaprojektować poszczególne węzły trapezu i trójkąta tylnego. Zdarza się, że wytwórca wykonuje wszystkie elementy konstrukcyjne ramy, jednak najczęściej, przynajmniej w pewnym zakresie, korzysta się z gotowych rozwiązań (np. haki, widelec). Przygotowanie takich elementów jest często pracochłonne, a przez to nieekonomiczne. Dodatkowo szeroko dostępne na rynku produkty komercyjne są bardzo dobrej jakości i zwykle dużo lżejsze (np. decydując się na widelec kompozytowy). Na etapie wyboru rurek/profili, konstruktor powinien uwzględnić kompatybilność wykonywanej przez siebie ramy z pozostałymi podzespołami, które wykonywane są w pewnych standardach. Zamawiając rury znanych producentów, kwestia ta jest przez nich zapewniona. Rury zawsze zamawia się z nieznacznym zapasem wymiarowym na obróbkę. Odcinek ten wskazany jest wyraźnie na dołączonej dokumentacji rysunkowej. Niektórzy wytwórcy dodatkowo oznaczają go kolorem. Następnie po zamocowaniu pojedynczej rury (np. rura górna lub rura dolna) w uchwycie z odpowiednio wyprofilowanymi zaciskami obrabia się mechanicznie jej końce. Sposób obróbki zależy od stopnia wyposażenia warsztatu (od dedykowanych frezarek, przez elektronarzędzia, po pilniki ręczne). W przypadku obróbki ręcznej, na końce rur można nakleić szablony (wykroje) wygenerowane przez program graficzny, odwzorowujące wzajemne przenikanie się profili, z uwzględnieniem zakładanych odstępów.

Metody przygotowania powierzchni elementów ramy do procesu lutowania wymagają użycia odpowiednich technik, zarówno czyszczenia, jak i modyfikacji powierzchni, zapewniających osiąganie najkorzystniejszych właściwości dyfuzyjnych, uwzględniając rodzaj materiałów łączonych i stosowanych lutów. Mają one zasadniczy wpływ na właściwości mechaniczne połączeń, a przez to na niezawodność pracy konstrukcji ramy. W praktyce, w zależności od właściwości łączonych elementów oraz charakterystyki używanych lutów, stosuje się różne metody przygotowania powierzchni, w celu jej rozwinięcia oraz zapewnienia spójności, zwilżalności i kapilarności: mechaniczne i chemiczne. Najczęściej stosowane metody mechaniczne usuwają większość zanieczyszczeń organicznych i nieorganicznych, zmieniając dodatkowo topografię powierzchni oraz jej reaktywność. W zależności od materiałów łączonych można ją realizować poprzez szlifowanie czy obróbkę strumieniowo - ścierną, choć najczęściej stosuje się chropowacenie materiałami ściernymi (papier, włókna, wełna metalowa). Metody mechaniczne umożliwiają ukonstytuowanie struktury geometrycznej warstwy wierzchniej, zapewniając maksymalne jej rozwinięcie, lecz nie gwarantują dobrego uaktywnienia powierzchni, stąd powinny być połączone z późniejszą obróbką chemiczną. Zazwyczaj pierwszym i końcowym etapem przygotowania powierzchni jest jej odtłuszczenie, zwykle za pomocą rozpuszczalników organicznych lub roztworów substancji powierzchniowo czynnych.

Pozycjonery do montażu ram unieruchamiają elementy podczas lutowania, zapobiegają ich odkształcaniu wskutek oddziaływania naprężeń cieplnych, zapewniają stabilność wymiarową i dogodny dostęp do węzłów. Są to zazwyczaj konstrukcje uniwersalne, które można dopasować do wielu typów użytkowych ram. Wszystkie punkty bazowe: główka ramy, rura podsiodłowa, mufa suportu i tylne haki są regulowane, co zapewnia możliwość uzyskania założonych wymiarów. Uchwyt taki, może być zamontowany na wsporniku w pozycji pionowej lub na stole w pozycji poziomej. Na rysunku 1 pokazano przykładowe pozycjonery do lutowania ram rowerowych.
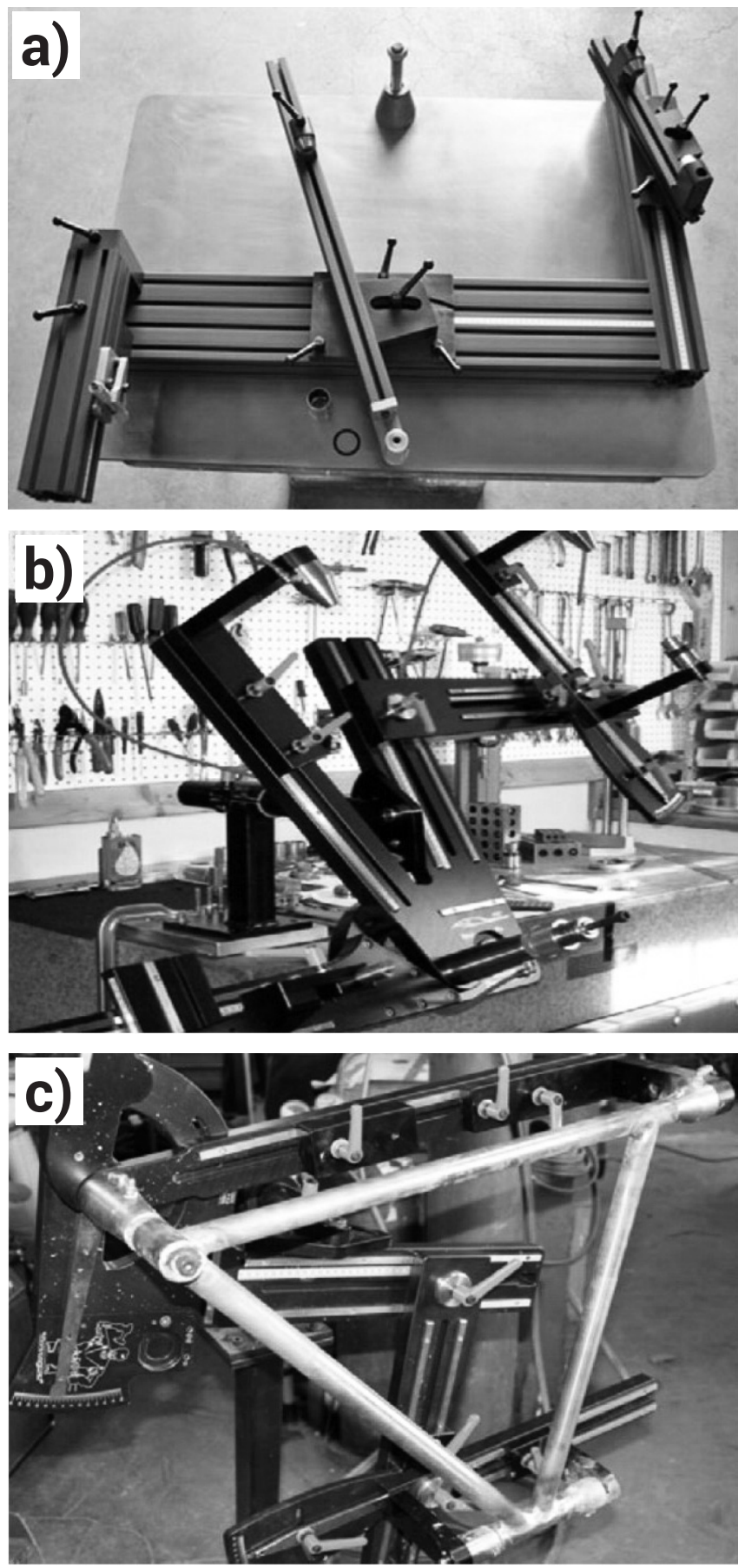

Rys. 1. Przykładowe stoły pozycjonujące stosowane do lutowania ram rowerowych [10]

Fig. 1. Examples of positioning tables used for bicycle frames brazing [10]

\section{Technologia lutowania ram rowerowych}

Powszechnie znane są dwa rodzaje wykonywania połączeń lutowanych: bezpośrednie/stykowe (fillet brazed) i z mufami (lugged) (rys. 2). Mufy (ang. lugs) są łącznikami pełniącymi jednocześnie funkcje wzmocnień najbardziej obciążonych miejsc konstrukcji - węzłów. Mufy zwiększają obszar przenoszący obciążenia, a nie koncentrują ich jak np. spoiny. Wykonuje się je przez przeróbkę plastyczną, odlewanie (metoda wosku traconego) lub rzadziej metodami spawalniczymi, niekoniecznie z tego samego materiału, co główne elementy ramy. Mogą one dodatkowo pełnić funkcję ozdobną, przyjmując dowolnie zaprojektowane przez użytkownika kształty [22], co $\mathrm{w}$ połączeniu z odpowiednim lakierowaniem stanowi dodatkowy walor estetyczny (rys. 3). Na wielu portalach dedykowanych użytkownikom 
rowerów, jako zaleta ram lutowanych wymieniana jest łatwość demontażu takich połączeń przez podgrzanie lutu do temperatury rozlutowania. Należy tu jednak zwrócić uwagę, że podczas wykonywania połączeń lutowanych twardych zachodzi zjawisko dyfuzji, zatem temperatura topnienia wytworzonego już połączenia, może być inna (zwykle wyższa) niż użytego lutu. W takich przypadkach istnieje prawdopodobieństwo zdeformowania czy uszkodzenia, a przez to utratę właściwości wytrzymałościowych przegrzanej ramy. W lipcu 2013 roku zespół autora niniejszego opracowania przygotował zgłoszenie patentowe 404706 proponujące zastosowanie muf wewnętrznych.
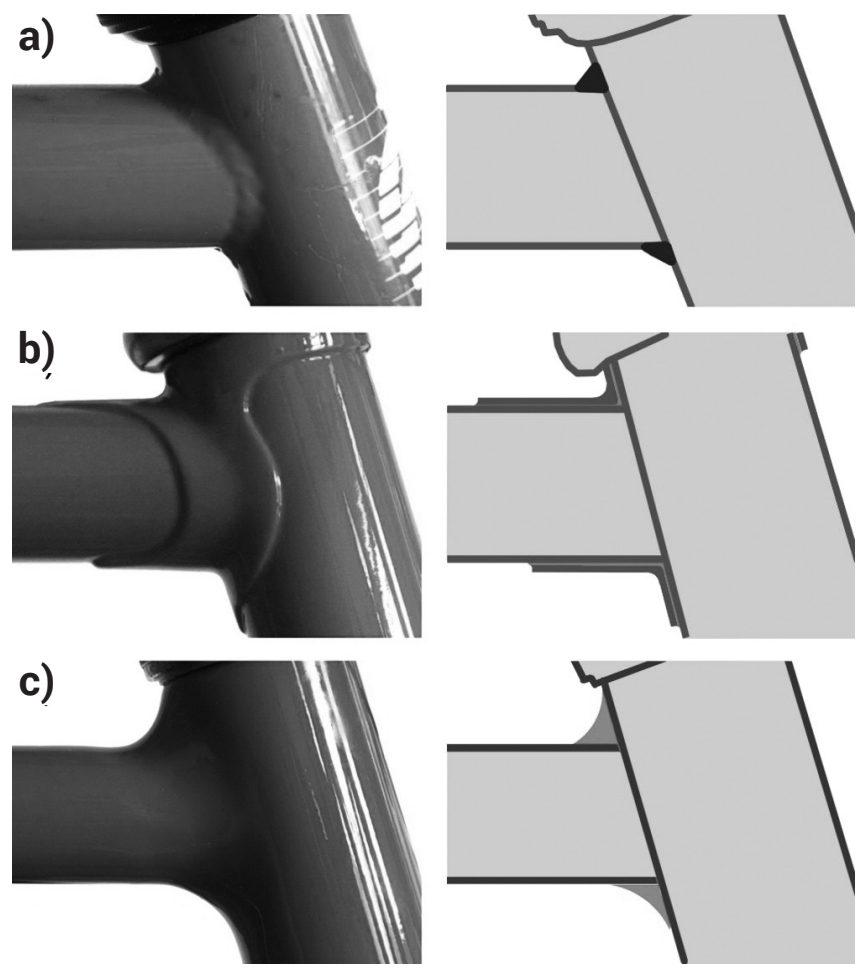

Rys. 2. Podstawowe metody wytwarzania ram rowerowych: spawanie (a), lutowanie z wykorzystaniem muf (b) i lutowanie bezpośrednie/stykowe (c)

Fig. 2. Basic methods of bicycle frames manufacturing: welding (a), lugged brazing (b) and fillet brazing (c)
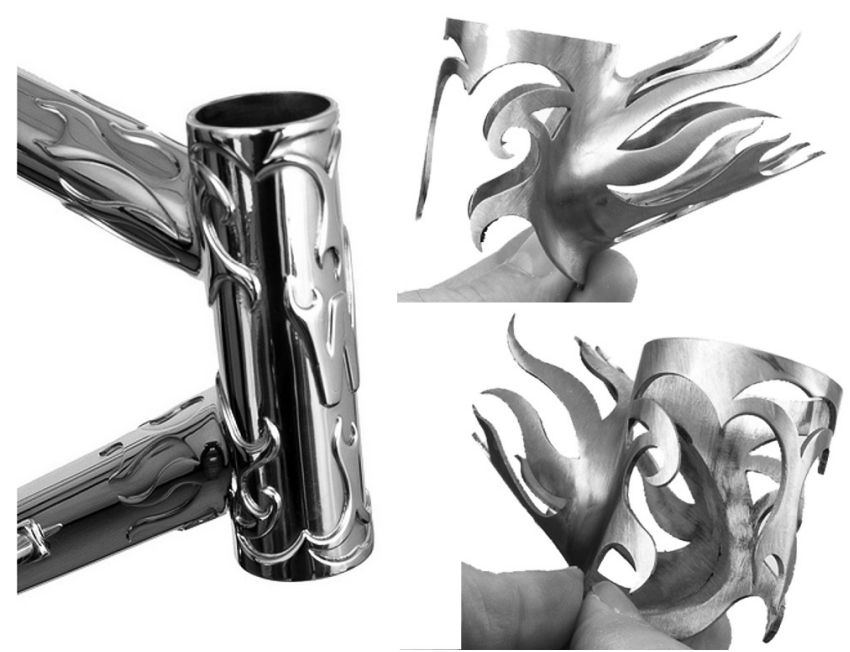

Rys. 3. Ozdobne kształty muf łączących rury ram rowerowych [22] Fig. 3. Ozdobne kształty muf łączących rury ram rowerowych [22]

Lutowanie bezpośrednie (tzw. stykowe, na styk) rur ram rowerowych (w praktyce najczęściej stalowych) wymaga znacznej precyzji, stąd zazwyczaj stosowanie ograniczone jest do produkcji jednorazowej, realizowanej w warszta- tach przez tzw. framebuilderów (pojawił się ostatnio polski odpowiednik - „ramiarz"). Nie oznacza to, że wytwarzane w ten sposób ramy są gorszej jakości. Doświadczeni praktycy są w stanie wyprodukować konstrukcje dopasowaną do anatomii i wymagań użytkowania, o bardzo dobrej wytrzymałości i funkcjonalności. Takie wytwarzane na zamówienie konstrukcje niejednokrotnie swoją ceną przewyższają konstrukcje wykonane przez uznanych producentów z branży. Lutowanie bezpośrednie elementów ramy wymaga dokładnego przygotowania i spasowania elementów łączonych. Szerokość szczeliny lutowniczej, należy dopasować do stosowanego lutu, tak aby wykazywała ona właściwości kapilarne. Kapilarność w technice lutowania jest samoczynnym wypełnianiem szczelin przez ciekły lut, wynikającym z różnicy między ciśnieniem powstającym wewnątrz szczeliny, a ciśnieniem otoczenia. Zależy ona od napięcia powierzchniowego, lepkości i gęstości lutu, a przede wszystkim właśnie od szerokości szczeliny. Największe ciśnienie kapilarne występuje dla szczelin poniżej 0,05 mm, wtedy jednak ich zdolność wypełnienia lutem, szczególnie w warunkach lutowania topnikowego, jest ograniczona [24]. Z punktu widzenia kapilarności zaleca się stosowanie szczelin lutowniczych w zakresie 0,05 $\div 0,2 \mathrm{~mm}$ [24]. Przy takich wymogach niezwykle istotne jest zapewnienie właściwego pozycjonowania łączonych elementów. Dla szczelin o wielkości ponad 0,3 mm większość lutów traci już właściwości kapilarne [24]. Wielu niedoświadczonych konstruktorów nie zwraca uwagi na ten ważny parametr, stosując znacznie większe odstępy. Wytrzymałość takich ram opiera się głównie na znacznym naddatku lutu (im większa pachwina tym większa wytrzymałość). Natomiast doświadczeni framebuilderzy są w stanie przewidzieć nieznaczne wydłużenie materiałów, będące wynikiem rozszerzalności cieplnej podczas operowania płomieniem acetylenowo-tlenowym, i stosują nieznacznie większe szerokości szczelin, uzyskując podczas lutowania danego węzła właściwości kapilarne.

Szczególnie korzystne jest zastosowanie lutowania w przypadku elementów o niewielkiej grubości ścianek, często dodatkowo cieniowanych. Znane są rozwiązania, gdzie stosuje się cieniowanie $0,8-0,5 \mathrm{~mm}$, a nawet $0,7-0,4 \mathrm{~mm}$, w których nazbyt duże obciążenie cieplne jest niedopuszczalne $[16,20]$. Najczęściej lutuje się mieszanką acetylenowo-tlenową, choć możliwe (ale rzadko praktykowane) jest zastosowanie gazów o mniejszym wydatku energetycznym (np. propan-powietrze). Zwykle reguluje się płomień z niewielką przewagą acetylenu - nawęglający i dobiera duży dziób palnika, w celu zredukowania prędkości wylotowej gazu, tak aby płomień nagrzewał dużą powierzchnię bez lokalnych przegrzań [18]. Ważne jest, aby zachować właściwą odległość palnika od grzanych elementów i nie przetrzymywać płomienia dłuższy czas w jednym miejscu, tylko równomiernie ogrzewać po obwodzie obie łączone rurki. Jest to szczególnie istotne podczas lutowania stopów aluminium, których temperatura topnienia często bywa nieznacznie wyższa od temperatury topnienia lutów, a sam materiał podczas ogrzewania nie zmienia barwy. Ewentualne przegrzanie okolic złącza zależy w znacznym stopniu od umiejętności lutowacza. Technika i kolejność lutowania zależy od preferencji oraz doświadczenia framebuildera. Po zamontowaniu ramy $\mathrm{w}$ przyrządzie pozycjonującym najczęściej zaczyna się od połączenia rury podsiodłowej z mufą suportu. Zwykle złącze obwodowe dzieli się na 2 lub 4 części i lutuje w etapach, zawsze symetrycznie. Należy pamiętać, że kierunek płynięcia roztopionego lutu determinuje grawitacja i wysoka temperatura, stąd połączenia najczęściej wykonuje się z góry na dół. Podczas procesu lutowania zawsze występuje wieloetapowa kontrola geometrii. 
Do lutowania najczęściej stosuje się spoiwa miedziane, mosiężne lub srebrne (do stali) i aluminiowe (do stopów aluminium) umożliwiające zapewnienie odpowiedniej wytrzymałości konstrukcji $[9 \div 11,15,18,20,23]$. Luty dobiera się w zależności od rodzaju materiałów łączonych, temperatury topnienia, a w przypadku większej produkcji również ceny. Do stali najczęściej wykorzystuje się luty mosiężne o temperaturze topnienia ok. $860-920^{\circ} \mathrm{C}$. Jest to zakres temperatur, mogący powodować zmiany właściwości elementów składowych (np. poddanych wcześniej obróbce cieplnej), zatem nie wszystkie gatunki stali można bez konsekwencji lutować tymi spoiwami. Jednakże znani producenci rur, na których to produktach pracuje większość framebuilderów, świadomie wytwarzają elementy z materiałów niezmieniających właściwości podczas lutowania, zatem nie trzeba np. dodatkowo przeprowadzać obróbki cieplnej. Łączenie z wykorzystaniem mosiądzu uchodzi za relatywnie ekonomiczne i łatwiejsze do wykonania - mniejsze wymagania tolerancji pasowania materiałów oraz kontroli temperatury, dlatego często polecane jest początkującym konstruktorom. Luty mosiężne równie chętnie wykorzystuje się w produkcji seryjnej (mufy), jak i jednostkowej (na styk). Do lutowania stali równie popularnie stosuje się luty na bazie srebra. Mimo niższej temperatury topnienia, w zależności od stopu ok. $600-830{ }^{\circ} \mathrm{C}$, i wyższej wytrzymałości połączeń, spoiwa te nie mogą konkurować z opartymi na stopach miedzi, głównie z uwagi na czynnik ekonomiczny. Wysoka cena srebra, połączona z jego niekiedy znacznym udziałem procentowym (nawet powyżej 70\%) powoduje, że często zastosowanie tych lutów jest nieopłacalne. Niemniej stopy srebra wykazują wiele korzystnych cech, jak zdolność wnikania w bardzo wąskie szczeliny czy niższe temperatury topnienia, a co za tym idzie mniejsze zmiany spowodowane obciążeniem cieplnym w złączach. Głównymi dodatkami w lutach srebrnych jest miedź (do 50\%) i cynk (do 40\%). Przed wprowadzeniem dyrektywy RoHS często wykorzystywano kadm, jako składnik obniżający temperaturę topnienia i ułatwiający lutowanie. Aktualnie do grupy często wykorzystywanych spoiw można zaliczyć luty mosiężne (np. Cu 407a, Cu 681, Cu 773 czy nieujęty w normie stop CuZnNi5) i srebrne (np. Ag 134, Ag 145, Ag 245) - oznaczenia wg PN-EN ISO 17672:2010. Dla wybranego rodzaju lutu należy dobrać odpowiedni topnik. Kryterium wyboru stanowi przede wszystkim zakres temperaturowy aktywności, ale również postać i związany z nią sposób aplikacji czy konieczność późniejszego oczyszczania. Do stali najczęściej wykorzystuje się topniki FH20, FH21 (luty mosiężne) i FH10, FH12 (luty srebrne), do aluminium FL10 i FL20 - oznaczenia wg PN-EN 1045:2001. Należy pamiętać, że większość topników oferowanych na rynku to produkty korozyjne, które po procesie lutowania trzeba bezwzględnie usuwać (rys. 4).

Poprawnie wykonane połączenia lutowane na styk oferują bardzo korzystne wskaźniki wytrzymałościowe, niezależnie od typu ramy i formy użytkowania roweru. Istnieją niszczące badania wytrzymałości konstrukcji czy poszczególnych węzłów, jednak nie są one praktykowane w produkcji jednostkowej. Złącza lutowane powinny być projektowane jako przenoszące siły tnące, natomiast w przypadku ram rowerowych, z uwagi na charakter konstrukcji, próby oceny wytrzymałości na ścinanie są niewłaściwe. Stosuje się jedynie proste próby warsztatowe oceny jakości wykonania złączy. Praktykujący framebuilderzy wytwarzają konstrukcje, w których nawet w przypadku wymagających warunków eksploatacyjnych czy nieoczekiwanych zdarzeń drogowych, zawsze w pierwszej kolejności zniszczeniu ulega materiał rodzimy. Znane są próby modelowania właściwości mechanicznych połączeń lutowanych ram rowerowych (rys. 5), ale aktualnie nie oferują żądanej dokładności oraz są zbyt mało popularne. Połączenia lutowane są zazwyczaj bardzo estetyczne, a w przypadku konieczności poprawy wyglądu lutowin, obrabia się je mechanicznie.
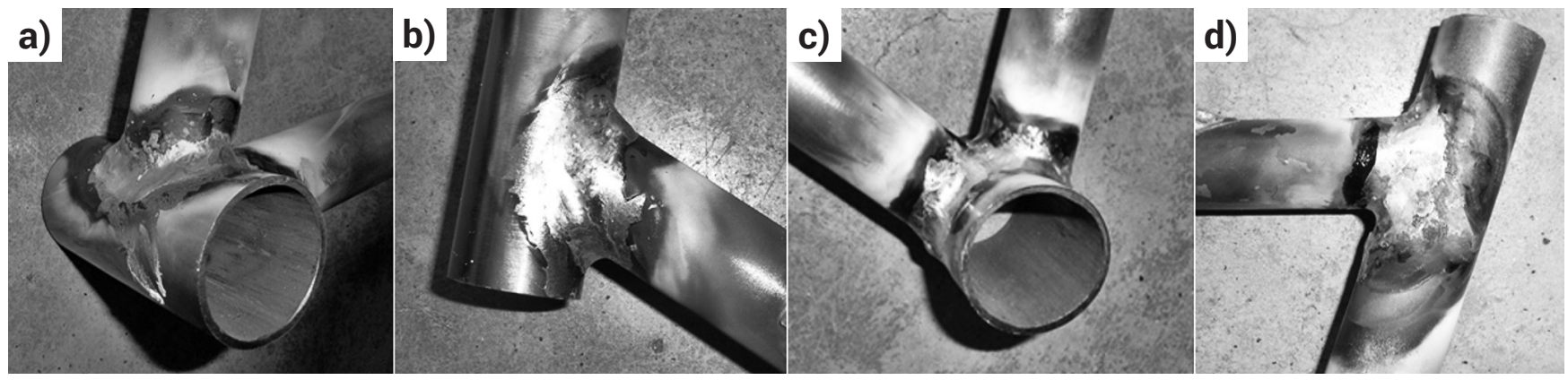

Rys. 4. Złącza lutowane rur ramy rowerowej bezpośrednio po procesie łączenia

Fig. 4. Brazed joints of bicycle frame pipes directly after bonding process
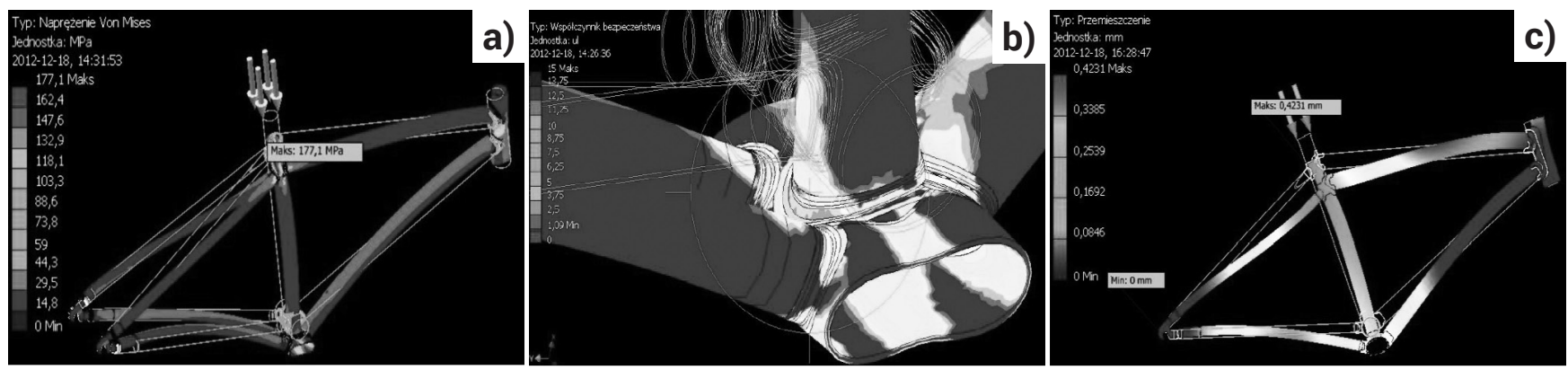

Rys. 5. Przykładowe wyniki analizy MES połączeń lutowanych ram rowerowych: a, b - lutowanie bezpośrednie, c - lutowanie na mufy (opracowanie własne)

Fig. 5. Exemplary results of FEM analysis of bicycle frames brazed joints: a, b - fillet brazing, c - lugged brazing (own work) 


\section{Metody poprawy parametrów użytkowych ram}

Aktualnie istnieje wiele sposobów poprawy przede wszystkim wytrzymałości mechanicznej ram rowerowych, ale również innych parametrów użytkowych, bez ingerencji w czynnik materiałowy. Co ważne, zwiększone wskaźniki wytrzymałościowe uzyskuje się często przy jednoczesnej redukcji masy ramy. Właściwości ram można ulepszać stosując m.in. obróbkę cieplną czy obróbkę skrawaniem względnie plastyczną mającą na celu zmianę kształtu i/lub

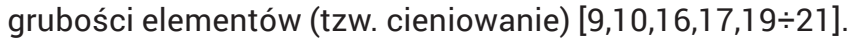
Cieniowanie pozwala na dopasowanie grubości ścianek rur do stanu naprężeń występującego w konstrukcji ramy. Proces ten realizuje się mechanicznie, hydraulicznie lub pneumatycznie [16]. Ponieważ zazwyczaj największe obciążenia występują w okolicach węzłów, w tych obszarach grubość elementów jest większa, niż w części środkowej (rys. 6). Znane są komercyjne rozwiązania, gdzie wykonuje się cieniowanie nawet do grubości $0,5 \mathrm{~mm}$ lub mniejszej (0,8-0,5 mm czy 0,7-0,4 mm) [16,20]. Najczęściej stosuje się cieniowanie pojedyncze lub podwójne (double butted/double gauge), choć znane są rozwiązania 3-, 4-, a nawet 5-krotnego cieniowania [21]. Cieniowanie rur prowadzi nie tylko do zmniejszenia ich masy, ale również nadaje ramie wysoką elastyczność (głównie w przypadku stali). W ostatnich latach pojawiły się na rynku ramy cieniowane promieniowo, $\mathrm{tj}$. konstrukcje $\mathrm{np}$. na zewnątrz okrągłe, wewnątrz owalne. Rozwiązania takie, szczególnie łączone z klasycznym cieniowaniem osiowym są jednak bardzo kosztowne.

Inną formą poprawy właściwości mechanicznych stosowanych komponentów jest tzw. wzmacnianie helikoidalne (helical reinforcements). Polega ono na wykonaniu wewnątrz rury (np. dolnej, podsiodłowej, sterowej) spiralnych
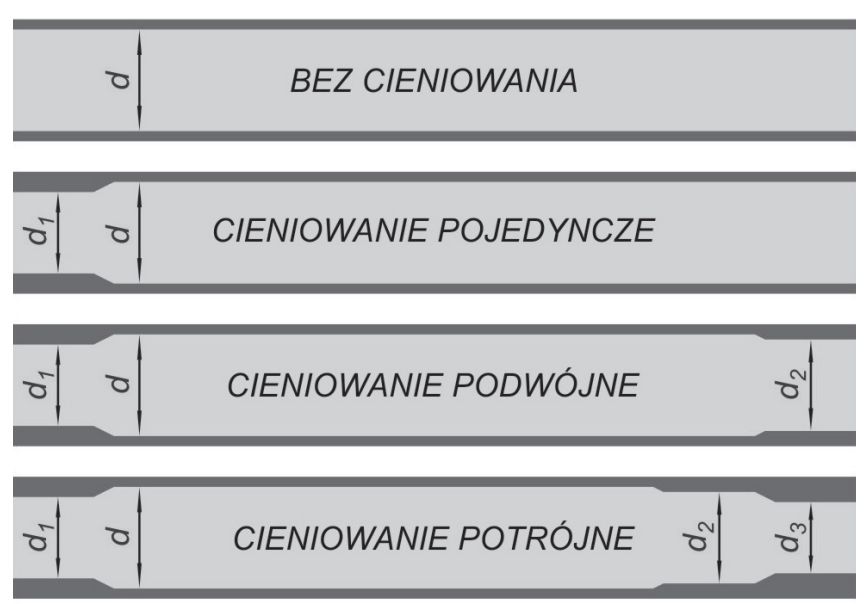

Rys. 6. Przykłady cieniowanych rur ram rowerowych

Fig. 6. Examples of butted pipes of bicycle frames

żeber o wymiarze ok. $1 \mathrm{~mm}$, które powodują dodatkowe umocnienie struktury profilu.

Obróbka cieplna, jakiej poddawane się często ramy rowerowe, polega na kontrolowanym temperaturowo i czasowo nagrzewaniu, wygrzewaniu i chłodzeniu konstrukcji. Celem tych zabiegów jest zmiana właściwości (głównie mechanicznych) wskutek ingerencji w strukturę materiału. Jej charakter zależy oczywiście od materiału ramy, ale decyzję o jej ewentualnym przeprowadzeniu dyktują również oczekiwane parametry funkcjonalne konstrukcji, a niekiedy czynniki ekonomiczne - skomplikowane operacje obróbki cieplnej w znacznym stopniu generują ostateczny koszt. Niekiedy wytwórcy ram rowerowych popełniają błędy projektowe, nie uwzględniając lub minimalizując kosztowo obróbkę cieplną, a jednocześnie planując np. dodatkowe wzmocnienia (tzw. zastrzały) koncentrujące naprężenia.

\section{Podsumowanie}

Lutowanie bezpośrednie jest wyjątkową techniką wytwarzania ram rowerowych, która z uwagi na bardzo dobre właściwości złączy, ich funkcjonalność i walory estetyczne, zdobywa coraz szersze grono odbiorców. Mimo relatywnie wysokiej ceny tak wykonanych konstrukcji oraz konkurencyjnej palety komercyjnych rozwiązań, wielu pasjonatów i profesjonalistów decyduje się na wybór tak spajanych ram. W Polsce tylko kilka osób zajmuje się usługowo produkcją ram lutowanych na styk. Są to rozpoznawalni w branży i poważani z uwagi na jakość oferowanych konstrukcji framebuilderzy. Ich produkty są cenione również przez zawodowych kolarzy, nie tylko w Polsce. Prognozuje się nieznaczny wzrost popularności tego typu produktów, gdyż doświadczeni framebuilderzy prowadzą szkolenia praktyczne dla amatorów, kończące się zwykle wykonaniem ramy wg projektu uczestnika. Wprawdzie kursy takie nie są tanie (kilka tysięcy złotych w Polsce, za granicą odpowiednio więcej), ale sposobność poznania aspektów praktycznych, połączona z możliwością wygenerowania unikatowej, dopasowanej pod konkretnego użytkownika geometrii ramy, kompensują poniesione koszty.

Autor pragnie podziękować znanym polskim framebuilderom i osobom związanym zawodowo z branżą rowerową za pomoc w przygotowaniu i merytorycznym zrecenzowaniu niniejszego opracowania. Szczególne wyrazy wdzięczności dla Panów: Orłowskiego "Orlowski Frames”, Rychtarskiego "Rychtarski - Bicycle Workshop, BIKES4YOU”, Uścieńskiego „Kajak Custom” oraz Nowaka i Folcika "Hultaj - bikes, technology, humanities”. 


\section{Literatura}

[1] Earth Policy Institute from Worldwatch Institute, Global Sherpa, 2010.

[2] Formosa N.: Up-and-comers rise in relevance to global market, Bicycle Retailer and Industry News, vol. 21, nr 11/2012.

[3] Ekiert A., Mojkowski J.: Zmieniamy samochody na rowery?, Angora, nr 28/2013.

[4] Polacy na rowerach, Komunikat z badań BS/119/2012, Fundacja Centrum Badania Opinii Społecznej, Warszawa, wrzesień 2012

[5] Lessard B.L., Nemes A.J., Lizotte L.P.: Utilization of FEA in the design of composite bicycle frames, Composites Vol. 26, Issue: 1, 1995.

[6] Liu, Thomas Jin-Chee; Wu, Huang-Chieh: Fiber direction and stacking sequence design for bicycle frame made of carbon/epoxy composite laminate, Materials and Design Vol. 31, Issue: 4, 2010.

[7] Fuerle F., Sienz J.: Decomposed surrogate based optimization of carbonfiber bicycle frames using Optimum Latin Hypercubes for constrained design spaces, Computers and Structures, Vol. 119, 2013.

[8] Lados D.A.: Material and Design Optimization for an Aluminum Bike Frame, Worcester Polytechnic Institute, 2012.

[9] Milson F.: Rower - regulacja, naprawa, konserwacja, GeoCenter International, Warszawa, 1996.

[10] Wilkinson M.: Bicycle Frame Building in the USA, Winston Churchill Travelling Fellow, 2011.

[11] Nelson R.: Bike frame races carbon consumer goods forward, Reinforced Plastics, vol. 47, Issue 7-8, 2003.

[12] Carbon composite sports bike, Reinforced Plastics, vol. 52, Issue 9, 2008.
[13] Cicero S., Lacalle R., Cicero R., Fernández D., Méndez D.: Analysis of the cracking causes in an aluminium alloy bike frame, Engineering Failure Analysis, Vol. 18, Issue: 1, 2011.

[14] Allsop J.D., Allsop M.G.: Modular composite bicycle frame, Composites Part A: Applied Science and Manufacturing (Incorporating Composites and Composites Manufacturing) Volume: 27, Issue: 4, 1996.

[15] Emiliani M.: The Metallurgy of Brazing, BIKE Tech, Bicycling Magazine's Newsletter for the Technical Enthusiast, 1982.

[16] Materiał ramy - to trzeba wiedzieć, magazyn rowerowy bikeBoard.

[17] Zinn L.: Zinn i sztuka serwisowania roweru górskiego, MZG, 2006.

[18] Derlukiewicz W., Ambroziak A., Białucki P.: Lutowanie akcesoriów do aluminiowych ram rowerowych, Przegląd Spawalnictwa nr 10/2010.

[19] Białucki P., Derlukiewicz W.: Właściwości złączy lutowanych w stalowych ramach rowerowych, Przegląd Spawalnictwa, nr 9/2010.

[20] Zwoliński J., Opracowanie własne z zakresu branży rowerowej, www.staff.amu.edu.pl

[21] Brandt A.: Cro-Mo nie klęka - rzecz o rowerach, wyprawa.nonstopadventure.pl

[22] http://waterfordbikes.com/

[23] Steel tube materials and processes, Reynolds Technology LTD, 2013.

[24] Mirski Z.: Sterowanie szerokością szczeliny lutowniczej w procesach spajania materiałów różnoimiennych, Prace Naukowe Instytutu Technologii Maszyn i Automatyzacji Politechniki Wrocławskiej nr 73, seria: Monografie nr 22, Oficyna Wyd. Politechniki Wrocławskiej, Wrocław 2000. 